\title{
Characteristics of alveolar cells and soluble components in bronchoalveolar lavage fluid from non-smoking aluminium potroom workers
}

\author{
A EKLUND, ${ }^{1}$ R ARNS, ${ }^{2}$ E BLASCHKE, ${ }^{3}$ J HED $^{4}$ S-O HJERTQUIST, ${ }^{5}$ K LARSSON, ${ }^{6}$ \\ H LÖWGREN, ' J NYSTRÖM, ${ }^{7}$ C M SKÖLD, ${ }^{14}$ G TORNLING ${ }^{1}$ \\ From the Department of Thoracic Medicine, ${ }^{1}$ Karolinska Hospital, Stockholm, Department of Health Service, ${ }^{2}$ \\ GA-Metall, Sundsvall, Departments of Clinical Chemistry and Clinical Immunology, ${ }^{3}$ Karolinska Hospital, \\ Stockholm, Department of Pathology, ${ }^{5}$ Sundsvalls Hospital, Sundsvall, National Institute of Occupational \\ Health, ${ }^{6}$ Solna, and Department of Lung Medicine, ${ }^{7}$ Sundsvalls Hospital, Sundsvall, Sweden
}

\begin{abstract}
Aluminium potroom workers have been reported to develop severe pneumoconiosis and bronchial hyperreactivity. The influence of inhalation of aluminium oxide and fluorides on the alveolar milieu was studied by bronchoalveolar lavage (BAL) in 14 male non-smoking potroom을 workers; 28 non-smoking healthy volunteers served as controls. The total numbers, concentrations, and proportions of various alveolar cells did not differ between the groups. The concentrations of $Z$ albumin and fibronectin in BAL fluid were significantly higher ( $\mathrm{p}<0.01$ for both) in the exposed $\overbrace{\Phi}$ workers, reflecting an increased alveolar capillary permeability and an activation of alveolar $\frac{\$}{5}$ macrophages (AMs). The concentration of angiotensin converting enzyme, another AM marker, $\stackrel{\mathbb{}}{-}$ was, however, decreased ( $\mathrm{p}<0.01)$ in the workers. The concentration of hyaluronan, a fibroblast $\overrightarrow{0}$ marker, did not differ between the groups. AMs from workers had a decreased capacity $(\mathrm{p}<0.05)$ interact with yeast $\mathrm{C} 3 \mathrm{~b}$ particles but not to ingest them. The expression of HLA-DR and OKM1 om the cell surfaces of AMs were equal in the two groups. The BAL findings were not accompanied restrictive lung disease in the workers. The fact that only a discrete alveolitis was found in the potroom workers may be due to a low grade of exposure to alumina and fluorides and to frequent use of respiratory protection equipment.
\end{abstract}

Aluminium potroom workers are exposed to alumina (aluminium oxide) dust and to particulate and gaseous fluorides. Aluminium plant employees may develop severe pneumoconiosis ${ }^{1-3}$ and bronchial hyperreactivity. ${ }^{48}$ No relation between atopic constitution and the development of airways obstruction in potroom workers has been observed. ${ }^{9}$

During the past decade bronchoalveolar lavage (BAL) has made possible the study of the alveolar milieu with regard to cells and soluble components under the influence of various agents. For example, the effect of smoking on cells and non-cellular substances has been well documented in several studies. ${ }^{10}$ The BAL technique also offers the opportunity to study the effects of occupational exposure to various agents potentially harmful on the alveolar space; those exposed to alumina have not to our knowledge been investigated.

Accepted 9 January 1989
To analyse the influence of the inhalation of alumina dust and fluorides on alveolar cells and soluble components we performed BAL in nonsmoking male potroom workers. The alveolar cell population was characterised with regard to cell 3 surface markers and phagocytic activity with flow cytofluorometry. The activity of the cells and the permeability of the alveolar capillary membrane were $ᄋ$ studied by measuring the concentration of fibronectin, $₹$ hyaluronan, angiotensin converting enzyme (ACE), 음 and albumin.

\section{Materials and methods}

STUDY POPULATION

Fourteen healthy male volunteers (mean age 42 , range 24-62) working in the potroom of the aluminium $\sigma$ production plant GA-Metall in Sundsvall, Sweden, were included in the study. The mean duration of

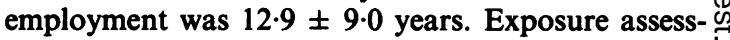


ments for different working tasks have been performed by measurements on eight hour samples from eight workers with the same type of occupation. The mean values of exposure of the study population were $1.77 \mathrm{mg} / \mathrm{m}^{3}$ (range $0.49-4.50$ ) for total dust and $0.31 \mathrm{mg} / \mathrm{m}^{3}$ (range $0 \cdot 10-0.50$ ) for gaseous and particulate fluorides. More than $65 \%$ of the alumina particles were smaller than $6 \cdot 3 \mu$. None of the workers had smoked during the past two years; previous cigarette consumption was $4 \cdot 3 \pm 8 \cdot 2$ (mean \pm SD) pack-years. All had a normal chest $x$ ray film and ECG.

Standard spirometry was performed in a rolling seal spirometer and lung volumes were measured in a body box. Diffusion capacity was measured by the single breath carbon monoxide technique. A group of 20 office workers from the same factory served as controls.

The control group for the BAL data consisted of 28 non-smoking healthy volunteers (mean age 25 , range 19-31) with normal chest $x$ ray films. The study had the approval of the local ethics committee and all subjects gave informed consent.

\section{BRONCHOALVEOLAR LAVAGE}

After premedication with morphine and scopolamine and local anaesthesia with $2 \%$ lignocaine (Xylocain, Astra, Södertälje, Sweden) a flexible fibreoptic bronchoscope (BF Type 4B2, Olympus Optical Co Ltd, Japan) was wedged in a bronchus in the middle lobe. Sterile saline solution at $37^{\circ} \mathrm{C}$ was instilled in five aliquots of $50 \mathrm{ml}$ and gently suctioned back as described earlier." The fluid was collected in a plastic bottle kept on ice.

\section{HANDLING OF ALVEOLAR CELLS}

The BAL fluid was strained through a double layer of Dacron nets. After centrifugation at $400 \mathrm{~g}$ for five minutes at $+4^{\circ} \mathrm{C}$ the supernatant was poured off and stored at $-70^{\circ} \mathrm{C}$ until analysed further. The cells were resuspended in Hank's balanced salt solution and a total cell count was performed in a Bürker chamber. The viability was evaluated by means of excluding trypan blue. The cell suspension was centrifuged a second time at $400 \mathrm{~g}$ for five minutes and the cells were resuspended in $4 \mathrm{ml}$ of RPMI 1640 culture medium (Labasco, Uppsala, Sweden) with the addition of gentamycin $5000 \mu \mathrm{g} / \mathrm{ml}$. The cell suspension was kept on ice and transported to the laboratory the same day.

A differential cell count was performed after the preparation of cytocentrifugal smears in a Cytospin 2 apparatus (Shandon, England) at $500 \mathrm{rev} / \mathrm{min}$ for three minutes. Cells were stained according to MayGrünwald Giemsa and 500 cells were counted.

BIOCHEMICAL ANALYSES IN BAL FLUID

Albumin (L-Alb) was determined by rocket immunoelectrophoresis ${ }^{12}$ and expressed as $\mathrm{mg} / \mathrm{l}$.

Angiotensin converting enzyme (L-ACE) activity was analysed according to Lieberman ${ }^{13}$ in concentrated BAL fluid as earlier described ${ }^{11}$ and expressed in U/L (nmol hippuric acid/min/l).

Fibronectin (L-Fn) was assayed by a double sandwich ELISA developed in our laboratory. The aliquots of BAL fluid and EDTA plasma were defrozen at $37^{\circ} \mathrm{C}$. Briefly, microtitre plates (Nunc, Denmark) were coated with rabbit antihuman fibronectin antibodies (Dakopatts AS, Glostrup, Denmark) in phosphate saline buffer, $\mathrm{pH}$ 7.2. After the addition of unconcentrated BAL fluid samples the plates were incubated at room temperature for two hours. Horse radish peroxidase labelled antihuman fibronectin (Dakopatts AS, Glostrup, Denmark) was added as second antibody and the plates were incubated for one hour. The amount of bound peroxidase, which is proportional to the amount of fibronectin in the sample, was measured by analysing its enzymic activity on $100 \mu \mathrm{l}$ orthophenylendiamine. The reaction was blocked by the addition of $150 \mu \mathrm{l} 1 \mathrm{M} \mathrm{H}_{2} \mathrm{SO}_{4}$ after incubation for six minutes and the absorbance at $492 \mathrm{~nm}$ was registered. Serum fibronectin of nephelometric quality from Behring-Hoechst (Frankfurt am Main, GFR) was used as a standard. Concentrations of L-Fn were expressed in $\mu \mathrm{g} / \mathrm{l}$. The detection limit was $10 \mu \mathrm{g} / \mathrm{l}$. Intra-assay and interassay CVs were $3.7 \%$ and $6.4 \%$, respectively.

Hyaluronan (L-HA) was analysed in principle according to Engström-Laurent using the Pharmacia HA test kit. ${ }^{14}$ Concentrations were expressed in $\mu \mathrm{g} / \mathrm{l}$.

\section{PHAGOCYTIC ASSAY}

A phagocytic assay using fluorescence quenching to differentiate between attachment and ingestion and recently adapted for flow cytometry was used to study receptor mediated phagocytosis. ${ }^{15}$ Cell pellets of alveolar macrophages (AMs) containing 3-6 $\times 10^{5}$ cells were resuspended in $200 \mu \mathrm{l}$ of Geys buffer (supplemented with $\mathrm{Ca}^{2+}$ and $\mathrm{Mg}^{2+}$ ) containing $5 \times 10^{6}$ serum opsonised heat killed yeast particles (yeast-C3b) per millilitre as prey. After incubation at $+37^{\circ} \mathrm{C}$ for 15 minutes the reaction was interrupted by adding ice cold buffer. Fluorescence of attached particles was quenched by adding trypan blue. The cell samples, treated and not treated with trypan blue, were then examined in an Ortho Spectrum III flow cytofluorometer (Ortho Diagnostic Syst, Westwood, Ma, USA). AMs interacting with fluorescent particles, attached or ingested, were analysed in samples not treated with trypan blue. This was expressed as " $\%$ interacting cells." The percentage of AMs with ingested particles ("\% ingesting AMs") was obtained by dividing the percentage of fluorescent cells after addition of trypan blue with the percentage of fluorescent cells before addition of the dye. This 
measurement was regarded as the ability of AMs to ingest particles.

\section{ANALYSIS OF CELL SURFACE MARKERS}

Before AMs were used in the immunoassays for surface antigens the autofluorescence was quenched with a technique that has recently been developed in our laboratory. Briefly, $100 \mu \mathrm{l}$ of room tempered noctyl-beta-D-glucopyranoside $(0.1 \%$ in PBS without EDTA) was added to the cell pellet. The suspension was mixed and incubated for five minutes in room temperature. Then $100 \mu \mathrm{l}$ of crystal violet $(2 \mathrm{mg} / \mathrm{ml}$ in sodium chloride) was added before a second incubation for five minutes on ice. The cell suspensions were washed twice in cold PBS-EDTA. The cell pellets were resuspended in $100 \mu \mathrm{l}$ of PBS-EDTA and were then used in the immunoassays for surface antigens. Ten microlitres of FITC conjugated monoclonal antibodies against HLA-DR (Becton-Dickinson Immunocytometry Systems, Mountain View, Ca, USA) or non-conjugated OKM1 (Ortho Diagnostic Systems Inc, Raritan, NJ, USA), diluted 1/10 in PBSEDTA, were added to the cell suspensions and incubated on ice for 30 minutes. Tubes containing anti-HLA-DR were washed and examined as described below. Tubes containing OKM1 were resuspended and incubated on ice with $100 \mu \mathrm{l}$ of FITC conjugated rabbit- $\mathrm{F}\left(\mathrm{ab}^{\prime}\right)_{2}$-antimouse immunoglobulin (Dakopatts AS, Glostrup, Denmark), diluted 1/20 in PBS-EDTA, for another 30 minutes. The cells were finally washed twice, resuspended in $1 \mathrm{ml}$ cold PBS-EDTA, and examined by flow cytofluorometry. The expression of HLA-DR antigens and C3bi-receptors (OKM1) was measured as the mean fluorescence intensity (MFI) of the cell population after subtraction of the background level calculated from control samples.

\section{Statistical analysis}

The observed values were not normally distributed and the results are given as medians and interquartile ranges unless otherwise stated. Results were compared with the Mann-Whitney test and correlations calculated according to Spearman.

\section{Results}

\section{LUNG FUNCTION}

The potroom workers showed moderate obstructive changes compared with controls. Mean values $( \pm S D) \underset{\sim}{\vec{\rho}}$ of vital capacity, total lung volume, residual volumeo (RV), forced expiratory volume in one second $\left(\mathrm{FEV}_{1}\right)$, and diffusion capacity for carbon monoxide, in per⿳亠口冋. cent of predicted values, were $95 \cdot 1 \pm 8 \cdot 5 \%$, $\mathbb{\mathrm { \Phi }}$ $101 \cdot 1 \pm 10 \cdot 4 \%, 126 \cdot 8 \pm 28 \cdot 8 \%, 94 \cdot 3 \pm 9 \cdot 2 \%$, and $89.6 \pm 13.3 \%$, respectively. RV and FEV differed $^{\text {कs }}$ significantly from controls $(p<0.01, p=0.05)$ but $\overrightarrow{0}$ the other values did not differ between the groups.

\section{GENERAL LAVAGE DATA}

As shown in table 1 in the potroom workers the median recovery of the instilled fluid was $66 \% ; 75 \%$ of the cells were viable. The total cell numbers, the cels concentrations, and the proportions of the various types of cells from workers and controls did not diffet significantly.

\section{SOLUBLE BAL COMPONENTS}

In the cell free BAL supernatant there was a signifiz cantly higher $(p<0.01)$ concentration of albumin in workers compared with controls, medians $61 \mathrm{mg} / \frac{\mathbb{B}}{\mathrm{B}}$ and $31 \mathrm{mg} / 1$ respectively (figure). Moreover, the fibronectin concentration in workers (median $75 \mu \mathrm{g} / \mathrm{l}$ L was raised $(p<0.01)$ compared with controls 84 ko $\mu \mathrm{g} / \mathrm{l}$ ). The ACE concentration (median $201 \mathrm{U} / \mathrm{l}$ ) significantly decreased $(p<0.001)$ in the workers compared with controls $(340 \mathrm{U} / \mathrm{l})$. The hyalurongro concentration did not differ significantly between the two groups, the medians being $22 \mu \mathrm{g} / \mathrm{l}$ and $26 \mu \mathrm{g} / \mathrm{s}$ respectively.

There was a significant correlation $(r=0.56$ $(p<0.05)$ between the concentrations of albumin and fibronectin in the BAL fluid from potroom workers No relation was found between any other of the various soluble components nor between any of these and the total alveolar cell number in the workers.

PHAGOCYTIC FUNCTION AND SURFACE ANTIGEN EXPRESSION OF AMS

The percentage of AMs interacting with yeast $\mathrm{C} 3 \dot{Q}$ particles showed a small but significant $(\mathrm{p}<0.05)$

Table 1 General characteristics of the BAL fluid recruited from 14 non-smoking aluminium potroom workers and 28 healthy non-smit volunteers (controls). Data are given as medians with interquartile ranges

\begin{tabular}{|c|c|c|c|c|c|c|c|c|}
\hline \multirow[b]{2}{*}{ Group } & \multirow{2}{*}{$\begin{array}{l}\text { Recovery } \\
(\%)\end{array}$} & \multirow{2}{*}{$\begin{array}{l}\text { Viability } \\
(\%)\end{array}$} & \multirow{2}{*}{$\begin{array}{l}\text { Total } \\
\text { cell count } \\
\left(\times 10^{6}\right)\end{array}$} & \multirow{2}{*}{$\begin{array}{l}\text { Cell conc } \\
\left(\times 10^{6} / l\right)\end{array}$} & \multicolumn{3}{|c|}{ Differential cell count } & \\
\hline & & & & & $A M$ & $L y$ & $P M N$ & \\
\hline $\begin{array}{l}\text { Potroom workers } \\
\text { Controls }\end{array}$ & $\begin{array}{l}66 \\
(57-73) \\
68 \\
(64 \cdot 8-75 \cdot 2)\end{array}$ & $\begin{array}{l}75 \\
(65-78) \\
84 \\
(80 \cdot 5-87 \cdot 0)\end{array}$ & $\begin{array}{l}9 \cdot 9 \\
(6 \cdot 4-16 \cdot 0) \\
14 \cdot 5 \\
(11 \cdot 7-21 \cdot 6)\end{array}$ & $\begin{array}{l}69 \cdot 1 \\
(45 \cdot 7-84 \cdot 2) \\
94 \cdot 0 \\
(65 \cdot 0-121 \cdot 5)\end{array}$ & $\begin{array}{l}87 \cdot 5 \\
(85 \cdot 0-95 \cdot 0) \\
88 \cdot 7 \\
(86 \cdot 2-93 \cdot 4)\end{array}$ & $\begin{array}{l}10 \cdot 0 \\
(5 \cdot 0-13 \cdot 0) \\
9 \cdot 0 \\
(5 \cdot 5-11 \cdot 2)\end{array}$ & $\begin{array}{l}1 \cdot 0 \\
(0 \cdot 0-2 \cdot 0) \\
1 \cdot 2 \\
(0 \cdot 6-2 \cdot 3)\end{array}$ & 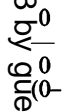 \\
\hline
\end{tabular}



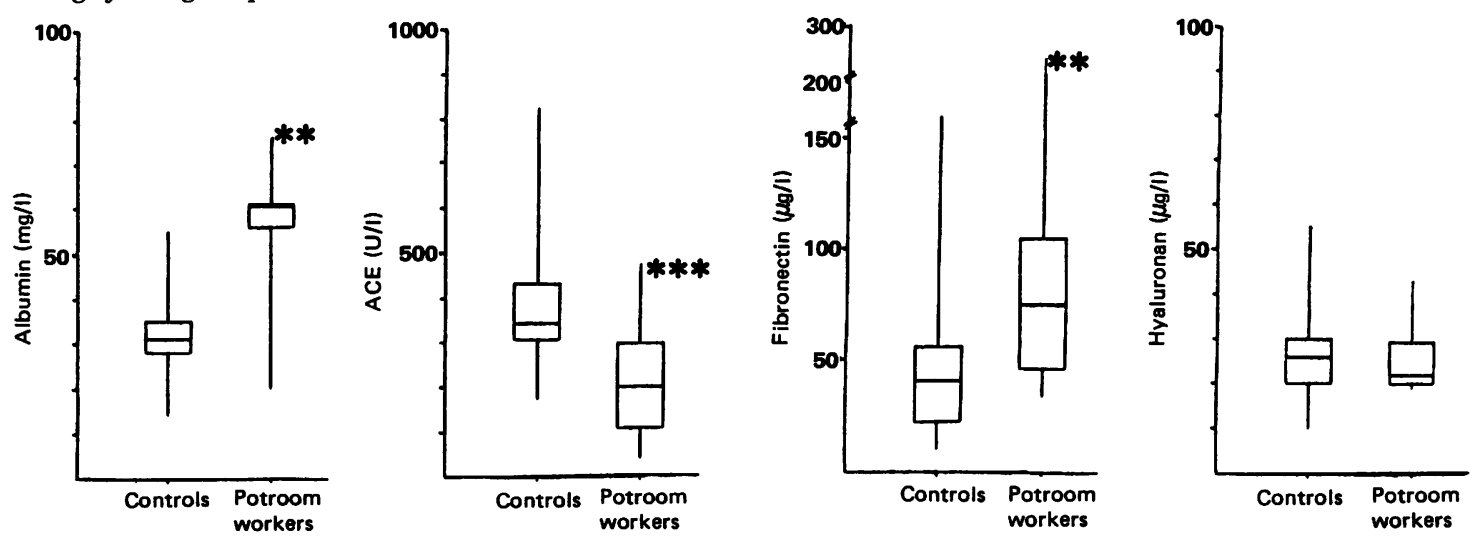

Results of biochemical analysis of non-cellular components in BAL fluid from 28 controls and 14 potroom workers. Boxes cover values within interquartile ranges, central horizontal line is at median, and vertical lines indicate ranges. ** $=p<0.01,{ }^{* * *}=p<0.001$.

Table 2 Expressions of $H L A-D R$ antigens and $O K M I$ (C3bi receptors) on alveolar macrophages (AM) from aluminium potroom workers and healthy controls. Expressions are given as mean fluorescence intensity (MFI) of the AM population as measured in a flow cytometer immunoassay

\begin{tabular}{llllll}
\hline & \multicolumn{2}{l}{$H L A-D R$} & & \multicolumn{2}{l}{ OKMI (C3bi) } \\
\cline { 2 - 3 } \cline { 6 - 6 } & Median & Range & & Median & Range \\
\hline Workers $(\mathrm{n}=11)$ & 225 & $154-233$ & & 68 & $54-107$ \\
Controls $(\mathrm{n}=13)$ & 203 & $198-212$ & & 85 & $51-105$ \\
\hline
\end{tabular}

decrease in workers (median $\mathbf{4 0 \%}$, interquartile (iq) range 36-44) compared with controls (median $47 \%$, iq range 41-49). The percentage of ingesting AMs did not differ between workers (median $63 \%$, iq range 54 67 ) and controls (median 67\%, iq range 60-72) implying that the ability of the AMs to ingest yeast C3b was not altered in the workers.

No significant differences in expression of HLADR and OKM1 (C3bi-receptors) could be detected between workers and controls as measured by the immunoassay in flow cytofluorometry (table 2).

\section{Discussion}

In the present study the influence of occupational exposure to alumina dust and particulate and gaseous fluorides on the alveolar milieu was analysed. Since others have found that potroom workers are at risk of developing pulmonary fibrosis ${ }^{1-3}$ we expected to find signs of a high intensity alveolitis. The alveolar cell concentration and the distribution of the cell subpopulations in the potroom workers, however, did not differ from the controls. The lack of increased recruitment of cells to the alveolar space in these workers indicate a low grade generation of chemotactic factors. The alveolar cells recruited from workers showed only a small decrease in receptor mediated phagocytosis and no effect on the phagocytes' ability to ingest particles. Furthermore, the expression of the DRantigen and receptors for complement factor $\mathrm{C} 3 \mathrm{bi}$ (OKM1) did not differ in workers and controls.

The analysis of non-cellular components in the BAL fluid offers further means to evaluate the presence and intensity of alveolitis. ${ }^{10}$ In the present study an increased concentration of albumin was found in the lavage fluid. Albumin leakage to the alveolar space is a sensitive marker of a local inflammatory reaction." Despite this indication of a local inflammation analysis of fluid phase markers of macrophage activation showed conflicting results since fibronectin was significantly increased but ACE significantly decreased in workers. The correlation $(r=0.56$, $\mathrm{p}<0.05$ ) found between the lavage albumin and fibronectin concentrations may possibly indicate a concomitant leakage of the two substances into the alveolar space. Fibronectin found in the lavage fluid could partly originate from cells outside the alveoli. The discrepancy in the findings of raised fibronectin and lowered ACE concentration in the lavage fluid could alternatively be explained by different regulatory systems for synthesis and release of the two substances from the AMs. Both substances may play a part in the inflammatory process eventually leading to fibrosis. Thus fibronectin plays a part in attracting fibroblasts and attaching cells to the intercellular matrix ${ }^{16}$ and ACE may interact in the inflammatory process. The low intensity alveolitis in these potroom workers did not result in restrictive lung disease and the normal lavage concentration of hyaluronan, a 
marker of fibroblast activation, is in accordance with this finding. ${ }^{17}$

Exposure to alumina and fluorides was well below the Swedish threshold limit values and the inhaled dose was also reduced by the frequent use of respiratory protection equipment in this plant. This might explain why the intensity of the alveolitis is of low grade.

In conclusion, in the present study analysis of BAL fluid recruited from aluminium potroom workers shows a low grade alveolitis expressed as an increased alveolar capillary permeability and altered macrophage function. It is not known if such a discrete alveolitis may play a part in the development of fibrosis. Most of the knowledge about cellular and fluid phase markers of inflammation in the alveolar space is based on reactions with more inflammatogenic substances than alumina. Also, it is often based on analysis of individuals with clinically manifest diseases. Whether the low intensity of the alveolitis found in the aluminium potroom workers in this study depends mainly on qualitative or quantitative factors could not be clarified but will be further analysed in continuing studies.

We thank director Ulf Bohlin at GA-metall AB for providing facilities to complete this study, the employees for participating as volunteers, and the staffs at the departments of lung medicine and pathology, Sundsvalls Hospital, and the departments of clinical immunology and chemistry at Karolinska Hospital, Stockholm.

Grant support by the Work Environmental Fund (87-0921), Stockholm, the Swedish Heart-Lung Foundation, the Swedish Medical Research Council (16X-105), and the Smedby Foundation.

\section{References}

1 Shaver CG, Riddell AR. Lung changes associated with the manufacture of alumina abrasives. $J$ Ind Hyg Toxicol $\overline{2}$ 1947;29:145-57.

2 Swensson $\AA$, Nordenfelt O, Forssman S, Lundgren K-D, Öhman H. Aluminium dust pneumoconiosis. Internationale Archiv für. Gewerbepathologie und Gewerbehygiene 1962;19:131-48.

3 Gilks B, Churg A. Aluminium-induced pulmonary fibrosis: dos] fibers play a role? Am Rev Respir Dis 1987;136:176-9.

4 Simonsson BG, Haeger-Aronsen B, Sjögren A, Eklundh G.C Bronchial hyperexcitability in workers exposed to aluminum salts. Scandinavian Journal of Respiratory Disease 1977;suppl 99:36-7.

5 Saric M, Zuskin E, Gomzi M. Bronchoconstriction in potroom workers. Br J Ind Med 1979;36:211-5.

6 Simonsson B, Haeger-Aronsen B, Sjöberg A, Rolf C. Bronchialreactivity after ceased occupational exposure in aluminum-salt. asthma. Eur J Respir Dis 1981;62 (suppl 113):195-6.

7 Simonsson BG, Sjöberg A, Rolf C, Haeger-Aronsen B. Acute and $\vec{\omega}$ long-term airway hyperreactivity in aluminum-salt exposed workers with nocturnal asthma. Eur J Respir Dis 1985;66:迥 105-18.

8 Wergeland E, Lund E, Waage JE. Respiratory dysfunction after $+\overrightarrow{+}$ potroom asthma. Am J Ind Med 1987;11:627-36.

9 Saric M, Godnic-Cvar J, Gomzi M, Stilinovic L. The role of atopy in potroom workers' asthma. Am J Ind Med 1986;9:239-42.

10 Reynold HY. State of art. Bronchoalveolar lavage. Am Rev Respir Dis 1987;135:250-63.

11 Eklund A, Blaschke E. Relationship between changed alveolarcapillary permeability and angiotensin converting enzymeactivity in serum in sarcoidosis. Thorax 1986;41:629-34.

12 Laurell C-B. Electroimmunoassay. Scand J Clin Lab Invest 1972;29(suppl 124):21-37.

13 Lieberman J. Elevation of serum angiotensin-converting enzyme (ACE) level in sarcoidosis. Am J Med 1975;59:365-72.

14 Engström-Laurent A, Laurent UBG, Lilja K, Laurent TC. Concentration of sodium hyaluronate in serum. Scand J CAinc Lab Invest 1985;45:497-504.

15 Hed J, Hallden G, Johansson SGO, Larsson P. The use fluorescence quenching in flow cytofluorometry to measure attachment and ingestion phases in phagocytosis in peripheral blood without prior cell separation. J Immunol Methods 1987; 101:119-25.

16 Rennard SI, Hunninghake GW, Bitterman PB, Crystal RG. پِ Production of fibronectin by the human alveolar macrophage: $\stackrel{D}{\Omega}$ mechanism for the recruitment of fibroblasts to sites of tissue $\vec{\overrightarrow{ }}$ injury in interstitial lung diseases. Proc Natl Acad Sci 1981; 음 78:7147-51.

17 Hällgren R, Eklund A, Engström-Laurent A, Schmekel B. Hyaluronate in bronchoalveolar lavage fluid: a new marker in sarcoidosis reflecting pulmonary disease. $\mathrm{Br}$ Med $J$ 1985; 290:1778-81. 